\title{
Restoring Strength to Recycled Fibres by Blending with Kenaf Pulp
}

\author{
Latifah J.*, Ainun, Z. M. A., Rushdan I. and Mahmudin, S. \\ Forest Research Institute Malaysia (FRIM) 52109 Kepong Selangor \\ * latifah@frim.gov.my(corresponding author) \\ Received $11^{\text {th }}$ April 2008, accepted in revised form $25^{\text {th }}$ November 2008.
}

\begin{abstract}
Recycled fibres are important sources for paperboard industry in Malaysia. There are various approaches to enhance the strength of recycled fibres which include mechanical treatment, chemical addition, and physical fractionation as well as blending with virgin fibres. In this study, the old corrugated containers (OCC) pulp was subjected to blending with virgin fibres of kenaf pulp. The OCC pulp was blended with kenaf pulp at $10 \%$ interval ranging from 0 to $100 \%$ addition. Comparison was also made with OCC blended with oil palm empty fruit bunches (EFB). It was observed that blending OCC with kenaf pulp had enhanced the strength of the recycled fibres.
\end{abstract}

Abstrak Gentian kitar semula adalah sumber penting untuk industri papan kertas di Malaysia. Terdapat pelbagai pendekatan untuk meningkatkan kekuatan gentian kitar semula termasuk rawatan mekanikal, penambahan bahan kimia, pemeringkatan fizikal dan juga pencampuran dengan gentian dara. Di dalam kajian ini, pulpa kotak beralun lama (OCC) telah dicampur dengan $10 \%$ pulpa kenaf untuk setiap peningkatan bermula dari 0 hingga $100 \%$ jumlah penambahan. Perbandingan turut dibuat dengan pulpa OCC yang telah dicampur dengan gentian tandan kosong kelapa sawit. Berdasarkan pemerhatian, pencampuran OCC dengan pulpa kenaf telah meningkatkan kekuatan gentian kitar semula.

(OCC, restore, strength, kenaf, pulp)

\section{INTRODUCTION}

Recycled paper and boards are important sources for pulp and paper industry in Malaysia. Of 20 paper mills in the country, only Sabah Forest Industries Sdn. Bhd. is an integrated pulp and paper mill. All of the 19 others utilise $95 \%$ waste papers as their main raw material except for Kimberly Clark (M) Sdn. Bhd. which uses 80\% imported virgin pulp. As such, the local recycledbased paper making industry has to find ways to achieve maximum strength from such an inferior starting material. The quality of secondary fibres deteriorates upon increased number of recycling. The strength loss will limit the number of recycles of waste paper and paperboard, hence limiting the usage of recycled fibre per unit production. The strength deterioration is due to the reduction in flexibility of rewetted pulp or reswelling ability of the fibre during drying $[1,2]$. There are different reported methods to restore the strength of recycled fibres which include mechanical beating $[3,4,5]$, fractionation $[6,7]$, use of chemical additive $[8,9,10]$, use of sodium hydroxide $[11,12]$ and blending $[13,14,15]$.
Recycled-based paper mills in Malaysia add a certain amount of imported virgin pulp into their production line. As such, this study is looking into the possibility of substituting imported virgin pulp with locally planted kenaf. Kenaf (Hibiscus cannabinus L.) is an annual herbaceous plant originated from Africa. It has gained popularity over the years due to its fast growth and strength characteristics. It is a unique fibre such that it's long bast fibres similar to softwood fibres whereas its core resembling hardwood fibres. The stalk is composed of $35-40 \%$ bast fibre and 60 $65 \%$ core fibres by weight [17]. Kenaf is currently being explored in developing countries as a viable raw material for pulp and paper and wood composites manufacturing. It has become as one of the promising raw materials for papermaking due to its adaptability in tropical and subtropical regions as well as its desirable fibre and pulp properties. Our earlier study on Malaysian cultivated kenaf [18] shows its potential for pulp and paper application. This study is aimed to restore the strength of recycled fibres by blending with virgin kenaf fibres. 


\section{MATERIALS AND METHODS}

\section{Preparation of raw materials}

Five-month-old kenaf of Khon Kaen variety was obtained from Forest Research Institute Malaysia (FRIM)'s plantation plot at Sabak Bernam, Selangor, Malaysia. OCC was obtained from Genting Sanyen Industrial Paper Sdn. Berhad, Banting, Selangor, Malaysia.

\section{Pulping of kenaf}

Kenaf bast was pulped via soda-anthraquinone process using $15 \mathrm{~L}$ rotary digester. The cooking conditions employed were as follows: active alkali: 17\%; Liquid:solid ratio: 6.5:1; cooking temperature: $170^{\circ} \mathrm{C}$. After digestion, cooked fibres were washed thoroughly with clean running water on a screen. The fibres were then disintegrated using hydrapulper for five minutes. The pulp was screened using Sommerville fractionator to remove shives. The screened pulp was pressed using spin dryer to remove water and subsequently kept in a plastic bag in a refrigerator.

\section{Handsheets making and testing}

Kenaf pulp was blended with OCC at $10 \%$ addition interval ranging from 0 to $100 \%$. For beating purpose, the kenaf pulp was beaten at $1000 \mathrm{rpm}$ using PFI mill prior to blending and papermaking. Handsheets were then made in a British handsheet former according to TAPPI Test Method T205 sp-02. Prior to testing, the handsheets were conditioned at $23 \pm 1{ }^{\circ} \mathrm{C}$ temperature and $50 \pm 2 \%$ relative humidity. The handsheets were evaluated for their physical and mechanical properties according to TAPPI standard methods as in Table 1. Comparison was then made with OCC blended with EFB as reported by Rushdan [19]. The surface structure of blended handsheets was observed using Scanning Electron Microscopy (SEM).

\section{Results and Discussion}

Observations by SEM on recycled fibre blended with kenaf pulp are shown in Fig. 1, 2 and Fig. 3. Figure 1 depicts the surface structure of OCC. Figure 2 illustrates the addition of unbeaten kenaf fibres into recycled fibres while Figure 3 shows the incorporation of the beaten fibres.

\section{Density}

Density is the most fundamental property and one of the important properties in evaluating the paper properties which indirectly measures the pulp flexibility. It influences every mechanical, physical and electrical property except sheet weight. Density is affected by the presence of materials that fill the voids in the sheet. Figure 4 shows that the densities for OCC pulp blended with kenaf fibres. The density of handsheets increased with increasing addition of beaten kenaf fibres. On the other hand, the density began to slightly descend for unbeaten kenaf when pulp was increased. The increase in handsheet density is believed to be associated with the replacement of more flexible fibres from kenaf pulp in the stiffened recycled fibres. Hornification (stiffening) or loss of swelling of the recycled fibre wall is a result of drying and rewetting cycle which thereby reduces the conformability of individual fibres $[1,20]$ and thus reduces the handsheet density. This was evident for less denser handsheets observed at the beginning of blending for beaten kenaf.

\section{Burst index}

Burst strength is an important strength requirement for corrugated container as it indicates resistance of a container to external and internal mechanical strengths. It is highly affected by the amount of interfibre bonding and individual fibre strength. Burst index is expressed as burst strength divide by grammage. As depicted in Figure 5, burst index increased upon increased addition of kenaf pulp into recycled fibres. Kenaf and oil palm fibres showed similar trend, nevertheless the former displayed noticeable improvement. Besides, increase in burst index was more pronounced for beaten kenaf as compared to the unbeaten kenaf. For instance, incorporation of 20,30 and 40\% virgin kenaf fibres had resulted in 15, 30 and $37 \%$ increases in burst index respectively. It shows that the strength enhancement was only conspicuous after $30 \%$ of kenaf addition. The increase in burst index is attributed to the flexibility and collapsibility of the fibres that results in increase of fibre bonding in paper sheet.

\section{Tensile index}

Tensile strength is a measure of resistance of paper to direct tension. Tensile index is expressed as tensile strength divide by grammage. Figure 6 shows the tensile index of recycled fibres blended with kenaf and EFB pulps. It was observed that 
TABLE 1: Standard Methods to Evaluate Pulp and Paper Properties

\begin{tabular}{|c|c|c|}
\hline No. & Standard Method & Properties \\
\hline 1. & ISO 5270: 1998 & Pulps-Laboratory sheets - Determination of physical properties \\
\hline 2. & ISO 536: 1995 & Paper and board - Determination of grammage \\
\hline 3. & ISO 534: 1988 & $\begin{array}{l}\text { Paper and board - Determination of thickness and apparent bulk density } \\
\text { or apparent sheet density }\end{array}$ \\
\hline 4. & ISO 5626: 1993 & Paper and board - Determination of folding endurance \\
\hline 5. & ISO 1924-2: 1994 & $\begin{array}{l}\text { Paper and board - Determination of tensile properties - part 2: Constant } \\
\text { rate of elongation method }\end{array}$ \\
\hline 6. & ISO 2758: 1983 & Paper - Determination of bursting strength \\
\hline 7. & MS 311: 1992 & $\begin{array}{l}\text { Methods of test for paper: Determination of tearing resistance } \\
\text { (Elmendorf Method) - First Revision }\end{array}$ \\
\hline
\end{tabular}

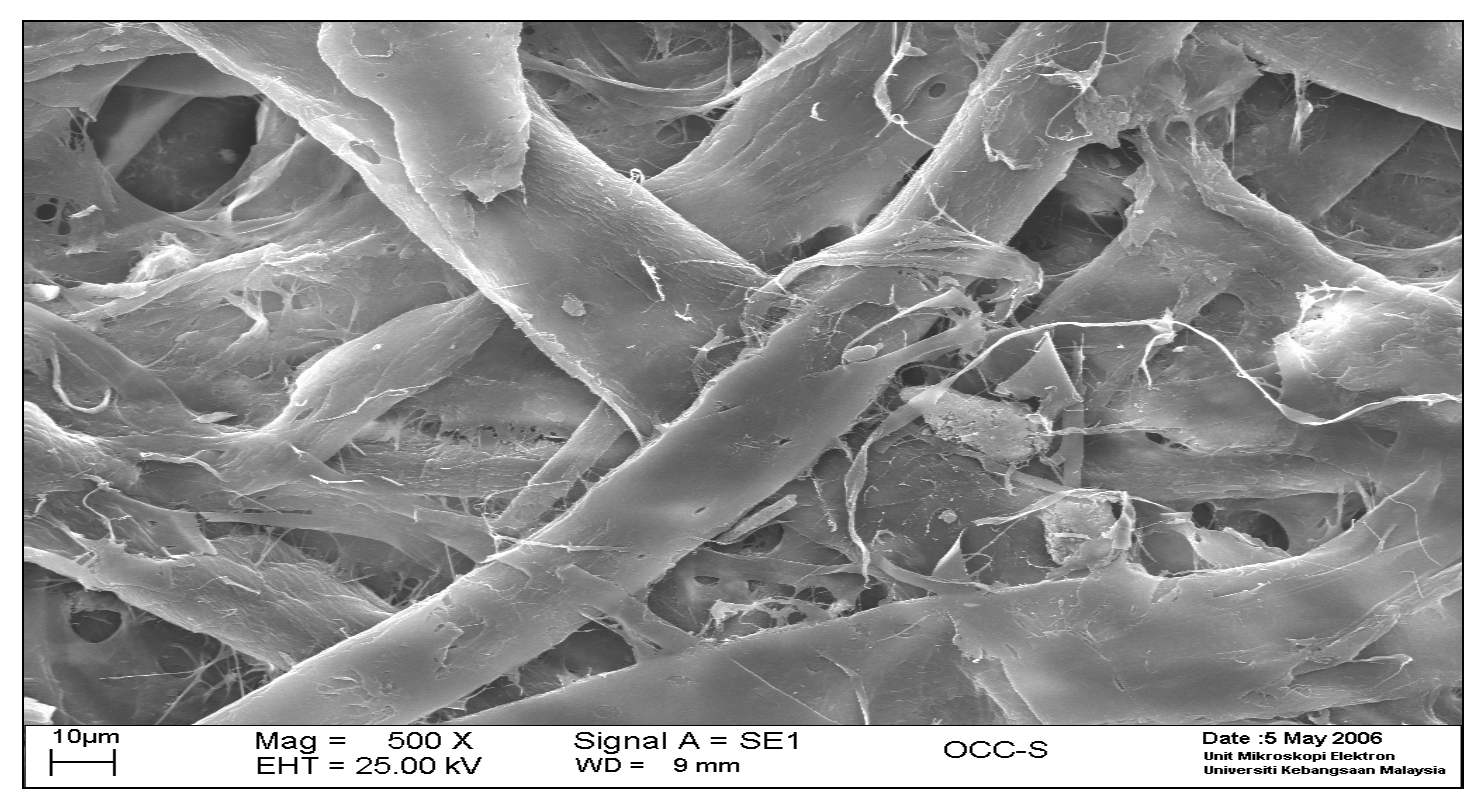

Figure 1. OCC 
Figure 1. OCC

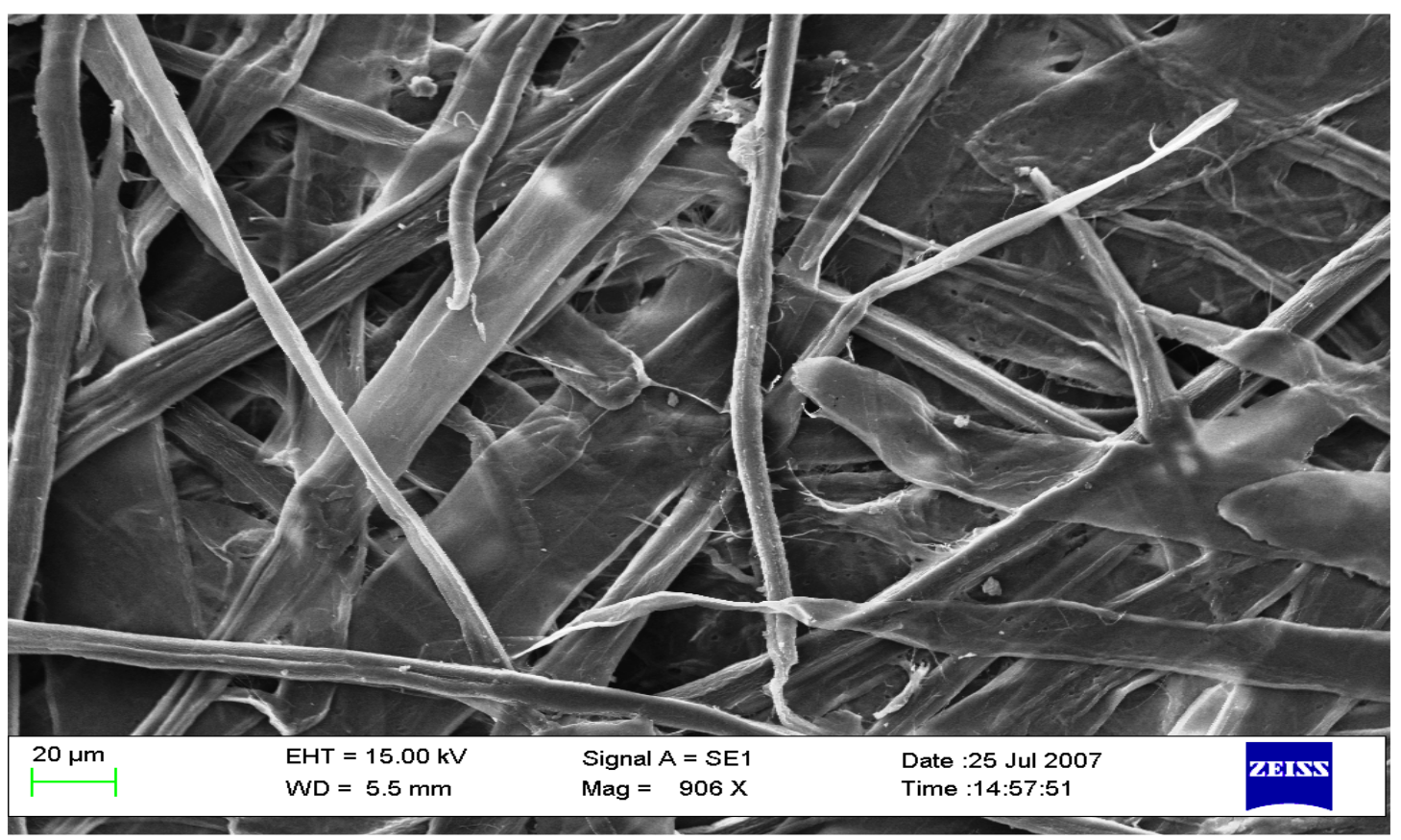

Figure 2. OCC blended with unbeaten kenaf pulp

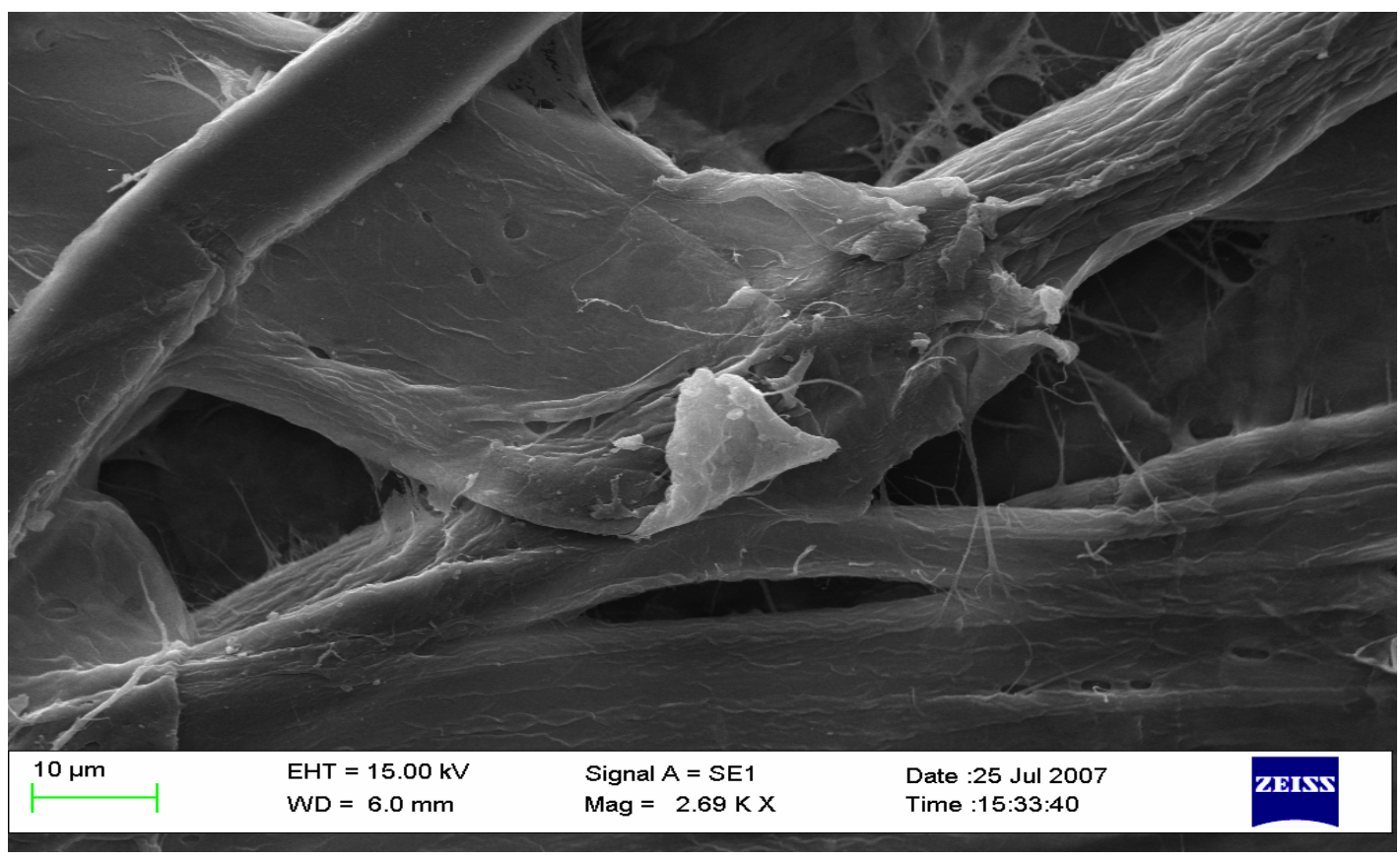

Figure 3. OCC blended with beaten kenaf pulp 


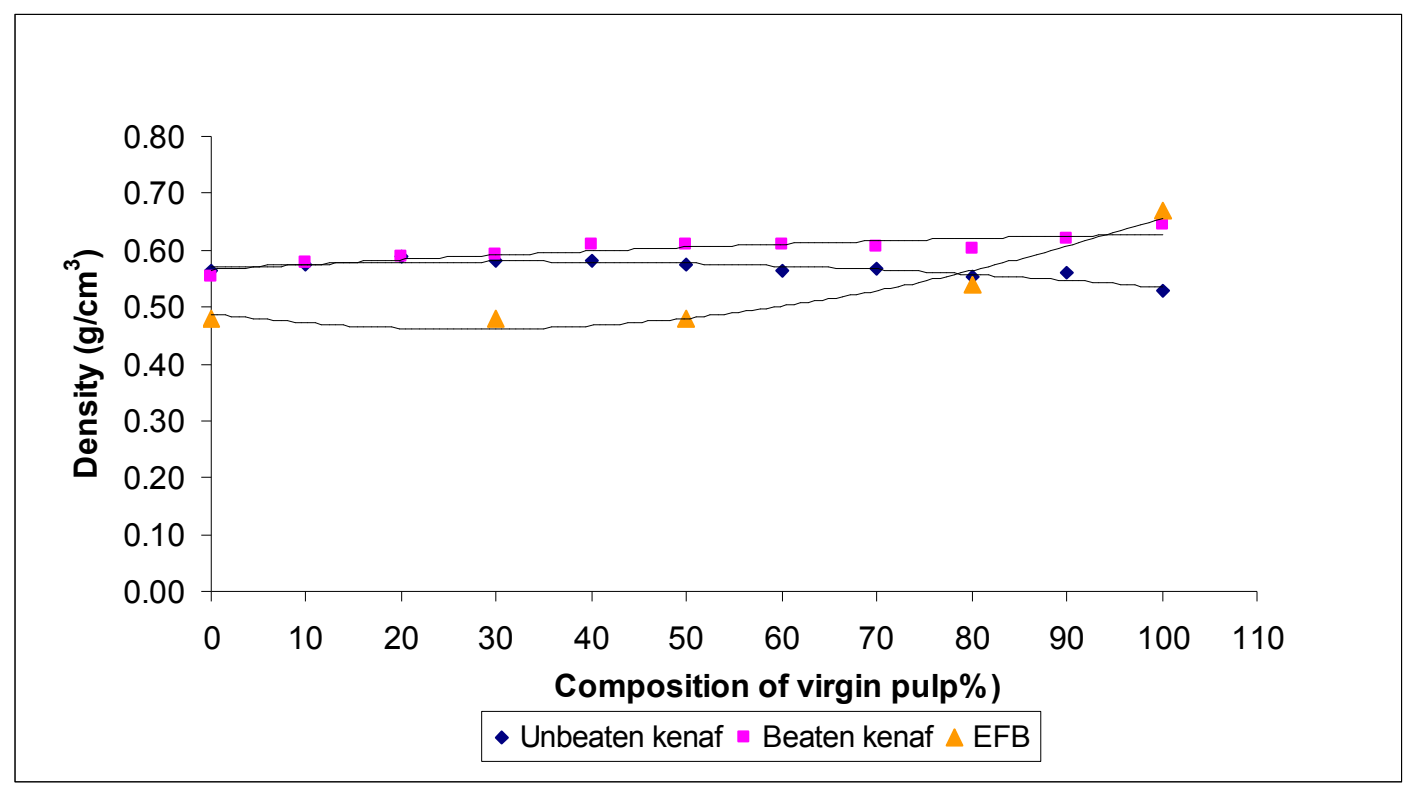

Figure 4. Effect of density upon pulp addition

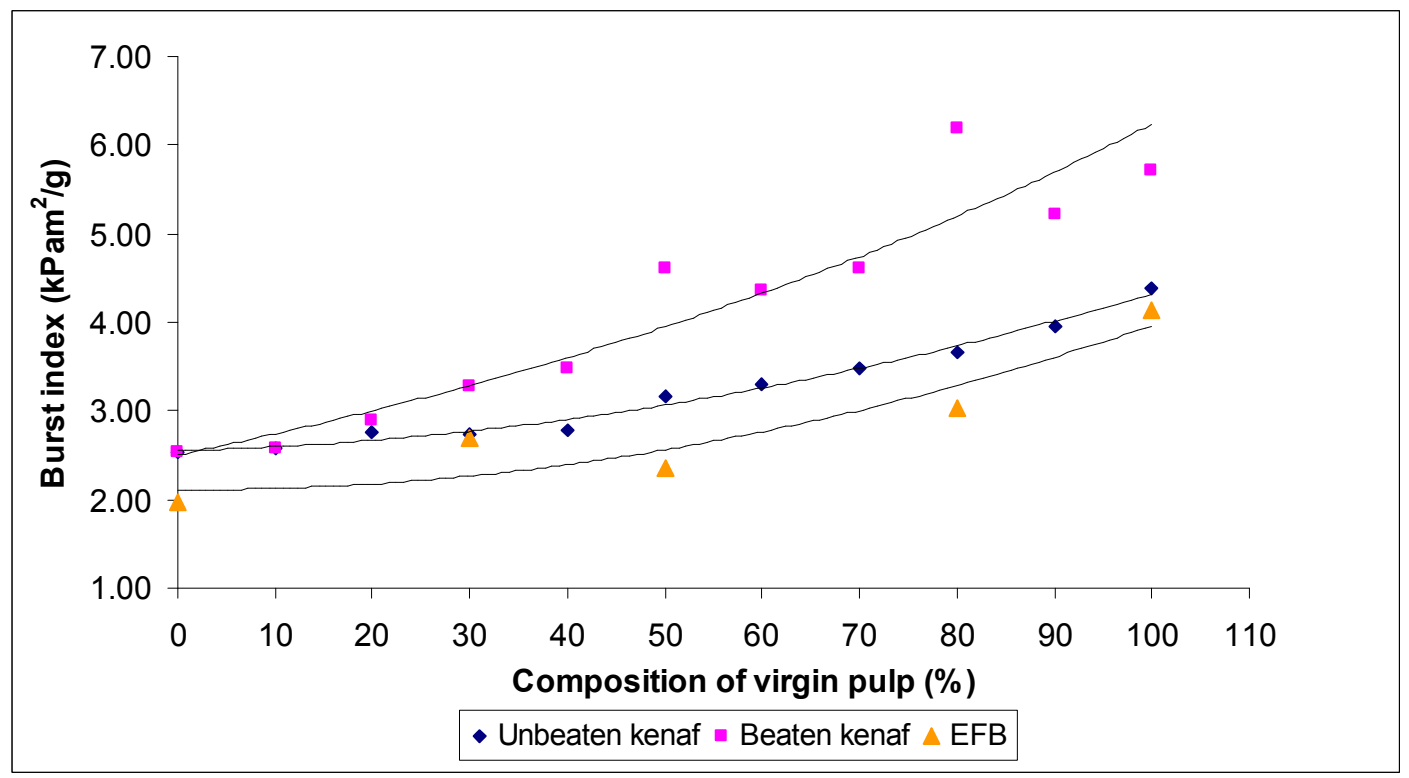

Figure 5. Effect of burst index upon pulp addition 
incorporation of only $10 \%$ kenaf pulp had resulted in notable increase in tensile index. It is evident that blending with kenaf results in greater strength enhancement of the tensile index as compared to oil palm fibres. The presence of active kenaf fibres on the inactive recycled fibres had increased the interfibre bonding which in turn increased the tensile strength [21]. The virgin fibre has greater flexibility which results in increased conformability and eventually enhances interfibre bonding. Beaten kenaf showed better tensile index when compared with the unbeaten kenaf. Adding 10, 20 and $30 \%$ of beaten fibres had resulted in 37, 42 and 59\% increases. Similar observations were also reported [21]. Beating is a process of internal and external fibrillation which has increased fibre flexibility and swelling capability; as a result, increased of interfibre bonding between fibres.

\section{Tear index}

Tearing resistance is dependant upon total number of fibres participating in the sheet rupture, fibre length and number and strength of the fibre-to-fibre bonds. Tear index is expressed as tearing strength divide by grammage. The effect of blending on tear index is shown in Figure 7. Tear index can only be enhanced after $30 \%$ of kenaf fibre addition. Tear index increased when pulp was increased. For instance, when 20 and $30 \%$ beaten kenaf pulp was added to the OCC, the corresponding increases in tear index were 4 and $5 \%$ respectively. It is interesting to note that strength enhancement was more pronounced when beaten kenaf was used. The reverse trend however was observed for oil palm fibres. Increasing the oil palm fibres had decreased the tear index. This is due to the fact that kenaf bast fibre is longer than that of EFB $[18,22]$.

\section{Fold}

As shown in Figure 8, fold increased with increasing addition of virgin fibres. Oil palm fibres also showed the same trend. A noticeable increase however was observed when beaten kenaf pulp was used. Incorporation of 30 and $40 \%$ beaten kenaf had resulted in rises of fold strength accounted for 69 and $169 \%$ respectively. Fold is generally affected by the flexing ability of the paper. As the fibre pliability increased, the paper flexing ability will also increase.

\section{CONCLUSION}

Blending OCC with virgin kenaf fibres had enhanced the strength of the OCC. Generally, incorporation of $30 \%$ virgin kenaf pulp had already increased all the mechanical strengths of the handsheets produced. Upon continuous addition, the mechanical strength relatively increased. The strength however was greatly restored when beaten virgin fibres was used. Beating has created internal and external fibrillation of the fibres, which in turn had created more bonded areas in the blended handsheets.

\section{ACKNOWLEDGEMENTS}

Financial support from Forest Research Institute Malaysia (FRIM), OCC supplied by Genting Sanyen Industrial Paper Sdn. Berhad and technical assistance rendered by Mr. Mohd. Shukri are gratefully acknowledged.

\section{REFERENCES}

1. Laivins G.V. and Scallan A. M. (1993). The mechanism of hornification of wood pulps. In Proceedings of the $10^{\text {th }}$ Fundamental Research Symposium. Oxford, UK, pp. 1235-1260.

2. Klungness J.H. and Caulfield D.F. (1982). Mechanism affecting fibre bonding during drying and aging of pulps. Tappi 83(12): 9497.

3. De Ruvo A. and Htun M. (1983). Fundamental and practical aspects of papermaking with recycled fibres. In: The role of fundamental research in papermaking, (ed. Brander J.) Vol. 1. Mechan. Eng. Publ, London, pp. 195-225.

4. DeFoe R.J. (1993). Optimal refining conditions for development of OCC pulp properties. Tappi 76(2): 157-161.

5. Howard R. C. and Bichard W. (1992). The basic effects of recycling on pulp properties. J. Pulp and Paper Science 18(4): J151-J159.

6. Howard R.C. (1995). The effects of recycling on pulp quality. In Technology of Paper Recycling. (ed. McKinney R.W.J.) Blackie Academic \& Professional, New York.

7. Abubakr S., Scott G. and Klungness J. (1994). Fibre fractionations a method of improving handsheets properties after repeated recycling. In Proceedings of the 


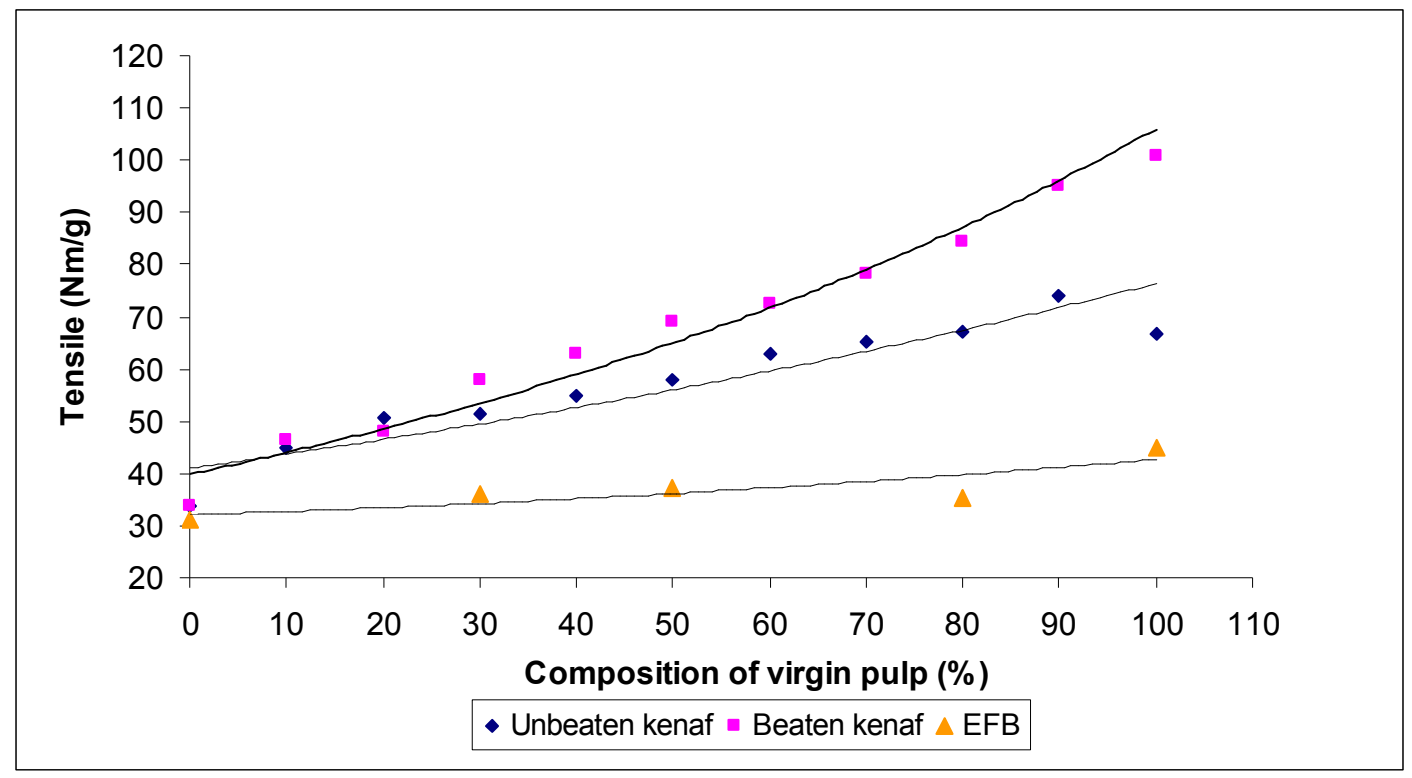

Figure 6. Effect of tensile index upon pulp addition

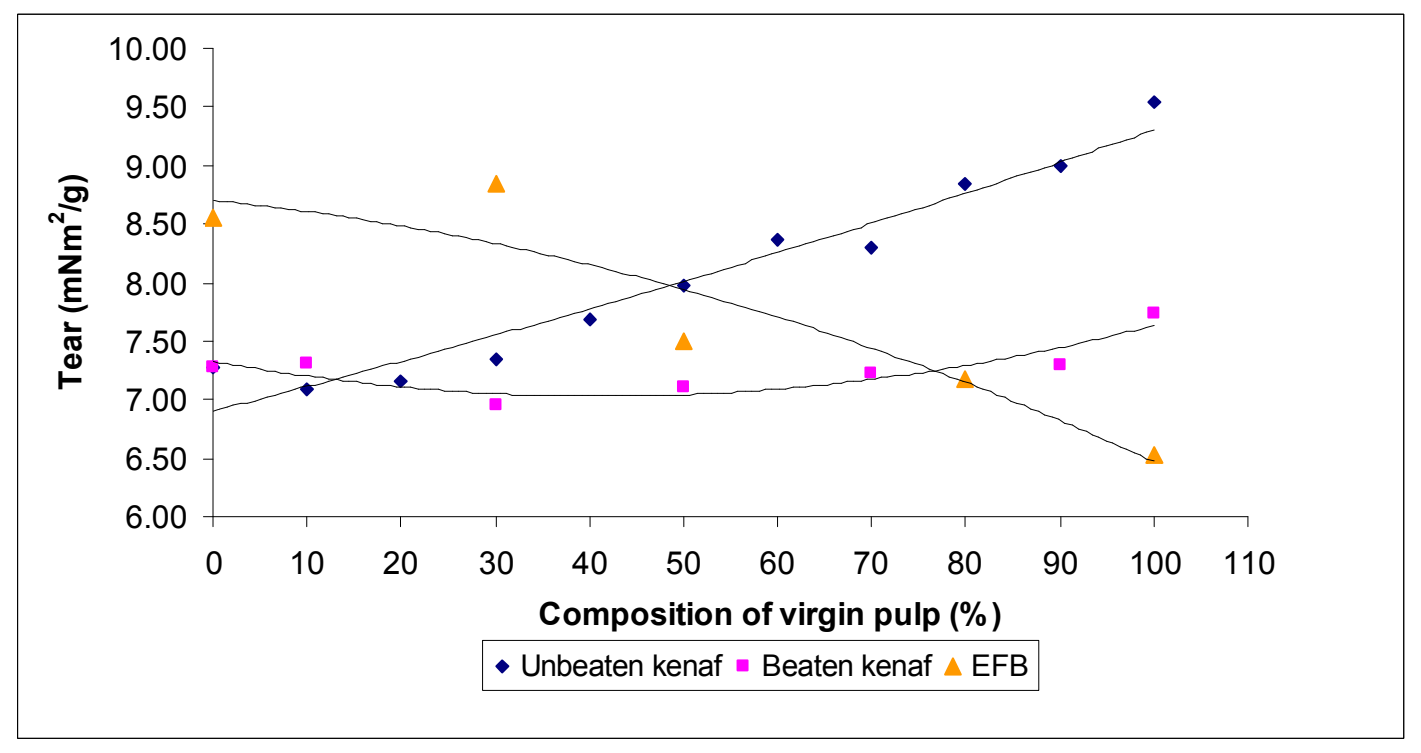

Figure 7. Effect of tear index upon pulp addition 
Malaysian Journal of Science 28 (1): $79-87$ (2009)

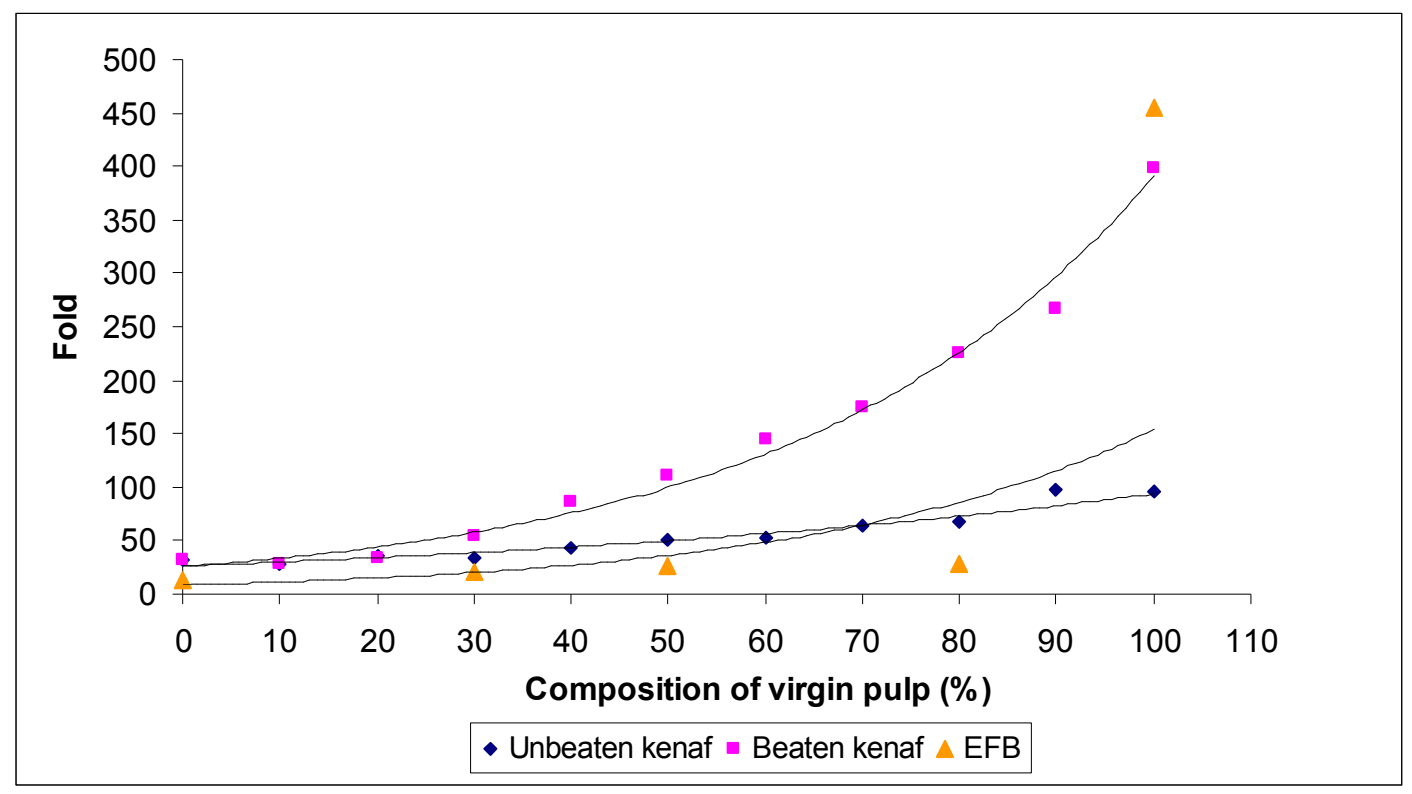

Figure 8. Effect of fold upon pulp addition 
1994 TAPPI Recycling Symposium. Atlanta, USA. pp. 309-312.

8. Ghosh A.K. (1999). Enhancement of paper strength of container materials using wet end additives in an acidic system. Appita Journal 47(3): 227-230.

9. Howard R.C. and Jowsey C.J. (1989). Effect of cationic starch on the tensile strength of paper. J. Pulp and Paper Science 15(6): 225229.

10. Rathi M.S. and Biermann C.J. (2000). Application of polyallylamine as a dry strength agent for paper. Tappi 83(12): 6269.

11. Freeland A. F. and Hrutfiord B. F. (1994). Caustic treatment of OCC for strength improvement during recycling. Tappi 77(4): 185-191.

12. Gurnagul N. (1995). Sodium hydroxide addition during recycling: effects on fibre swelling and sheet strength. Tappi 78(12): 119-124.

13. Szwarcsztajn E. and Przybysz K. 1974. Zellstoff und Papier 23(7): 203-207.

14. Valade, J.L., Law, K.N. and Peng Y. X. (1994). Influence of blending virgin pulp on the papermaking potential of reslushed fibres. Progress in Paper Recycling, pp. 6067.

15. Minor J.M., Scott, C.T. and Attala R.H. (1993). Restoring bonding strength to recycled fibres. 1993 Recycling Symposium. TAPPI, Atlanta. pp. 379-385.

16. Parsad B., Jakubsen S., Kocurek M. (1995). Georgia kenaf project. In proceedings of Tappi Pulping Conference. Tappi Press: Atlanta, GA, pp. 329-335.

17. Sharmiza A., Latifah J., Mahmudin S. and Mohd. Nor, M.Y. (2005). Suitability of locally planted kenaf for pulp and paper applications. Proceedings of $3^{\text {rd }}$ USMJIRCAS International Symposium. JIRCAS (eds. Tanaka R. and Cheng L.H.) Tsukuba, pp. 54-57.

18. Rushdan I. (2003). Structural, mechanical and optical properties of recycled paper blended with oil palm empty fruit bunch pulp. J. Oil Palm Bulletin 15 (2): 28-34.

19. Jayme G. 1944. Mikro-Quellungsmessungen an Zellstoffen, Papier-Fabr. Wochbl. Papierfabr.6, pp. 187-194.
20. Wan Rosli W. D., Zainuddin Z. and Roslan S. 2005. Upgrading of recycled papers with oil palm fibre soda pulp. Industrial Crops and Products 21: 325-329.

21. Peh T.B., Khoo K.C. and Lee, T.W. 1976. The Malaysian Forester 39(1): 23-37. 